\title{
EFFECT OF CINNAMIC ACID AND MODIFIED ATMOSPHERE \\ PACKAGING ON STORAGE LIFE OF PLEUROTUS OSTREATUS (OYSTER MUSHROOMS)
}

\author{
BIMALI JAYAWARDENA* AND H. ANUSHA PRIYADARSHANI SILVA \\ Department of Chemistry, University of Kelaniya, Kelaniya, Sri Lanka
}

\begin{abstract}
In Sri Lanka Oyster mushroom (Pleurotus ostreatus) is a popular cultivated variety of mushrooms. It is considered as a good source of proteins and fiber. The shelf life of Pleurotus ostreatus is short and it deteriorates rapidly due to browning and microbial infestations. Polyphenol oxidae is the enzyme responsible for enzymatic browning. Polyphenol oxidase inhibitors are used to inhibit the browning reaction. Cinnamic acid is an inhibitor of polyphenol oxidase of mushroom. In the current study cinnamic acid treatment and modified atmosphere packaging were used to extend the storage life of Pleurotus ostreatus. The $\mathrm{ID}_{50}$ value of cinnamic acid for polyphenol oxidase of Pleurotus ostreatus was $3.42 \mathrm{mM}$. Mushrooms were dipped in $0.50 \mathrm{mM}$, $1.25 \mathrm{mM}$ and $2.00 \mathrm{mM}$ solutions of cinnamic acid and stored in polyethylene bags for $4,7,11$ and 14 days at $4^{\circ} \mathrm{C}$. After the storage period the organoleptic properties were evaluated. After 07 days of storage product started to deteriorate in the controls and some treated samples. Mushrooms treated with a cinnamic acid concentration of 1.25 $\mathrm{mM}$ and packed in polyethylene bags and stored at $4^{\circ} \mathrm{C}$ maintained the organoleptic properties up to 11 days. The storage life of Oyster mushroom can be extended up to 11 days at $4^{\circ} \mathrm{C}$ using $1.25 \mathrm{mM}$ cinnamic acid dipping and packaging in 150 gauge $(38 \mu \mathrm{m})$ polyethylene bags with 3:1 surface area to weight ratio.
\end{abstract}

Keywords: Oyster mushroom; polyphenol oxidase; cinnamic acid; modified atmosphere packaging

\footnotetext{
*Corresponding author E mail: bimali@kln.ac.lk
} 


\section{INTRODUCTION}

Oyster mushroom is regarded as one of the commercially important edible mushrooms throughout the world. It consists of a number of different species including Pleurotus ostreatus, Pleurotus sajor-caju, Pleurotus cystidiosus, Pleurotus cornucopiae, Pleurotus pulmonarius, Pleurotus tuber-regium, Pleurotus citrinopileatus and Pleurotus flabellatus. Oyster mushroom has many advantages as a cultivated mushroom: rapid mycelial growth, high ability for saprophytic colonization, simple and inexpensive cultivation techniques and several kinds of species available for cultivation under different climatic conditions. One of the key features of Oyster mushroom is that its unique ability to adapt to a wide range of lignocellulosic substrates (Rajapakse et al. 2007). Cultivation of mushrooms became popular among people in Sri Lanka as an agribusiness since 1980s (Kumara \& Edirimanna 2009). In Sri Lanka only a few mushroom species are popular among growers and from those Oyster mushroom predominates (Rajapakse et al. 2007). However most of the growers as well as consumers in Sri Lanka prefer two strains of Pleurotus ostreatus commonly known as American Oyster and Lanka Oyster. Oyster mushroom like other edible mushrooms is low in calories, sodium, fat and cholesterol, while rich in protein, carbohydrate, fiber, vitamins and minerals. These nutritional properties make mushroom a very good dietary supplement. Mushrooms are a good protein source. The fruiting bodies of Pleurotus ostreatus contain significant amounts of essential amino acids. Mushrooms are also considered to provide protection against cardiovascular diseases and cancers. Oyster mushrooms are very effective in reducing the total plasma cholesterol and triglyceride level and thus reduce the chances of arthrosclerosis and other cardiovascular and artery related disorders (Alam et al. 2008). Within the 29 species of edible and medicinal mushrooms Pleurotus ostreatus and Agaricus bisporus are considered to be the richest source of lovastatin. The antioxidant, antihyperglycemic, and antimicrobial effects of edible mushrooms are well documented (Kalac, 2013).

Mushrooms are only protected by a thin porous epidermal structure. They lack a cuticle or a specialized epidermal structure to control the rate of transpiration as in 
higher plants. Therefore their epidermal layer does not provide protection against quick superficial dehydration that causes important quality losses. Since $90 \%$ of mushroom weight at harvest is water, scientists hypothesized that freshly harvested mushrooms transpire at the same rate as the fruiting sporophore. Therefore dehydration occurs and it causes the quick deterioration of harvested mushrooms (Ares et al. 2007). Apart from dehydration, enzymatic browning is a major cause of post harvest losses in edible mushrooms. Polyphenol oxidase (PPO) enzyme is responsible for post harvest browning in mushrooms. Many factors contribute for the browning reaction. Such as availability of phenolic substrates such as tyrosine, dihydroxynapthalene (DHN) amounts of PPOs, activation of latent forms of the enzymes and access for the melanogenous substrates to the active enzymes.

All the above mentioned factors differ from tissue to tissue and evolve in a complicated manner during sporophore development, after harvest and during storage (Jolivet et al. 1998). Approximately $98-99 \%$ of tyrosinase in mushroom is present in its latent or inactive form. So only the remaining active form has a potential for enzymatic browning during senescence or when the tissue is damaged during post harvest handling (Brennan et al. 2000). Latent PPOs can be activated by proteases such as trypsin, treatment with acids, or other agents which promote unfolding and other conformational changes, such as fatty acids, detergents and other denaturants. Apart from enzymatic browning, browning discoloration occurs due to action of the bacterial strains present on the mushroom. Pseudomonas tolaasii is responsible for causing 'bacterial blotch disease' by formation of brown color blotches on the surface of sporophore. Mushrooms are prone to microbial attack due to high water content and the lack of a cuticle. Refrigeration and relative humidity control are key factors that are used to extend the shelf life of mushrooms. In Sri Lanka Pleurotus ostreatus is packed in polyethylene packages. The polythene film helps to prevent water loss and creates a modified atmosphere inside the package. Mushrooms can tolerate up to $5 \% \mathrm{CO}_{2}$ inside the package. If the levels of $\mathrm{CO}_{2}$ exceeds this limit it is phytotoxic and the product starts to deteriorate. Apart from packaging, developing chemical compounds to prevent enzymatic browning is of interest. Cinnamic acid and its derivatives are effective inhibitors of tyrosinase isolated from Agaricus bisporus (Shi 2005). In the current study 
attempts were made to develop post harvest strategies to extend the shelf life of Pleurotus ostreatus using cinnamic acid and modified atmosphere packaging.

\section{MATERIAL AND METHODS}

Fresh untreated whole American Oyster mushrooms (Pleurotus ostreatus) were purchased from 'Ranmuthu Bimmal' sellers, Kandhaliyadhdhapalu, Ragama, Sri Lanka. Mushrooms were screened for uniform size $(8 \pm 1 \mathrm{~cm})$ and appearance. Diseased, damaged and extremely large or small sized mushrooms were discarded to minimize the biological variability.

Cinnamic acid was purchased from Fluka (USA). Dimethyl sulfoxide (DMSO) and L-3, 4-dihydroxyphenylalanine (L-DOPA), and all the other chemicals were purchased from Sigma-Aldrich (India).

\section{Extraction and partial purification of mushroom tyrosinase from Pleurotus} ostreatus

Mushroom tyrosinase was extracted according to the method described by Haghbeen et al. (2004) with slight modifications.

Fresh American Oyster mushrooms $(150.00 \pm 0.01 \mathrm{~g})$ were homogenized in $\mathrm{Na}_{2} \mathrm{HPO}_{4}-\mathrm{NaH}_{2} \mathrm{PO}_{4}$ buffer $(\mathrm{pH}$ 6.0, $120.0 \pm 0.1 \mathrm{~mL})$ for two minutes at room temperature $\left(30 \pm 1^{\circ} \mathrm{C}\right)$, filtered through a muslin cloth. The filtrate was centrifuged at $13500 \times \mathrm{g}$ at $4 \pm 1^{\circ} \mathrm{C}$ for 30 minutes (MISTRAL-400, refrigerated centrifuge, U.K.). The supernatant was fractionated by Ammonium sulphate precipitation. Fraction collected with $70 \%$ Ammonium sulphate had the highest activity and was used to calculate the $\mathrm{ID}_{50}$ value.

\section{Enzyme activity assay}

Diphenolase activity of mushroom tyrosinase was performed according to the method described by Horowitz et al. (1960). The enzyme 0.006 units in $\mathrm{Na}_{2} \mathrm{HPO}_{4}-$ 
$\mathrm{NaH}_{2} \mathrm{PO}_{4}$ buffer $(\mathrm{pH} 6.0,3.90 \pm 0.01 \mathrm{~mL})$ was mixed with L-DOPA (0.02 M 1.00 \pm 0.01 $\mathrm{mL}$ ). The absorbance was monitored at $475 \mathrm{~nm}$ for 05 minutes using a UV-visible spectrophotometer. (OPTIMA, sp-3000 plus, Japan).

\section{Determination of ID $_{50}$ value for cinnamic acid}

$\mathrm{ID}_{50}$ value of cinnamic acid on mushroom tyrosinase was determined according to the method described by Masamoto et al. (1980).

Varying concentrations of cinnamic acid were dissolved in DMSO in a volumetric flask. The enzyme extract (0.006 units) was placed in $0.9 \mathrm{~mL}$ of $\mathrm{pH} 6.8$ $\mathrm{Na}_{2} \mathrm{HPO}_{4}-\mathrm{NaH}_{2} \mathrm{PO}_{4}$ buffer with and without the inhibitor. The solutions were incubated at $25 \pm 1{ }^{\circ} \mathrm{C}$ for two minutes. The absorbance was measured at $475 \mathrm{~nm}$ using UV-visible spectrophotometer. (OPTIMA, sp-3000 plus, Japan).

The percent inhibition of mushroom tyrosinase was calculated according to the following equation.

$$
\text { Percentage inhibition }=\frac{(A-B)-(C-D)}{(A-B)} \times 100
$$

A: optical density at $475 \mathrm{~nm}$ without test sample

B: optical density at $475 \mathrm{~nm}$ without test sample and enzyme

C: optical density at $475 \mathrm{~nm}$ with test sample

D: optical density at $475 \mathrm{~nm}$ with test sample but without enzyme

Cinnamic acid which induces the $50 \%$ inhibition was obtained by plotting the percent inhibition of tyrosinase $v s$ log cinnamic acid concentration. Each data point represents the mean of three replicates.

\section{In vivo application of cinnamic acid}

Based on the $\mathrm{ID}_{50}$ value a concentration series of cinnamic acid was prepared by dissolving cinnamic acid in DMSO $(10.00 \pm 0.01 \mathrm{~mL})$ and mixing with distilled water $(90.0 \pm 0.1 \mathrm{~mL})$. A drop of Turkey red oil, a commercial surfactant (saponified castor oil) was added as an emulsifying agent.

Samples of fresh whole unwashed mushrooms each containing 200.00 $\pm 0.01 \mathrm{x}$ $3 \mathrm{~g}$ were immersed in $1 \mathrm{~L}$ of $0.50,1.25$ and $2.00 \mathrm{mM}$ cinnamic acid aqueous solutions for 5 minutes at $30 \pm 1^{\circ} \mathrm{C}$. The control samples were treated with a mixture of distilled 
water, DMSO (9:1) ratio to which a drop of Turkey red oil was added. The treated samples were washed with water and allowed to air dry. The samples were packed into 150 gauge $(38 \mu \mathrm{m})$ polyethlene bags with $3: 1$ surface area to weight $(40.00 \pm 0.01 \mathrm{~g})$ ratio, sealed and stored at $4 \pm 1^{\circ} \mathrm{C}$ for 14 days. Percent weight loss, reflectance, color, aroma and overall acceptability, were measured after 4, 7, 11 and14 days of storage.

\section{Weight loss}

Weight loss was determined by weighing mushrooms before and after the storage period.

$$
\text { Weight loss }(\mathrm{g} / 100 \mathrm{~g})=\frac{\mathrm{W}_{0}-W_{f}}{\mathrm{~W}_{0}} \times 100
$$

Where $\mathrm{W}_{0}$ is the weight on the first day and $\mathrm{W}_{\mathrm{f}}$ is the weight on final storage day.

\section{Reflectance}

On every sampling day 3 samples were randomly selected from each sample set, treated with $0.50,1.25$ and $2.00 \mathrm{mM}$ of aqueous cinnamic acid solutions and from the control. A uniform slice of $3.5 \mathrm{~cm}$ in length and $1.5 \mathrm{~cm}$ in width was removed from all the samples. The slice was taken from an angle of $70^{\circ}$ at a height of $\sim 2.0 \mathrm{~cm}$ from the bottom and $\sim 1.0 \mathrm{~cm}$ from the top. Each slice was placed inside a glass slide and the reflectance was measured at $450 \mathrm{~nm}$ (GBC UV-Visible Cintra 202Spectrometer, Australia) using a fresh unwashed sample as the reference. Each value is an average of three reflectance measurements for each sample.

\section{Color index}

Post harvest browning of unwashed whole Pleurotus ostreatus mushrooms stored at $4 \pm 1{ }^{\circ} \mathrm{C}$ and $30 \pm 1^{\circ} \mathrm{C}$, were continuously assessed for 14 days and 5 days using RGB images (digital camera; FinePix JV 160, Fuji Film). These images were put 
together (AdobePhoto Shop CS4 11.0 software programme) and a color index for post harvest browning of Pleurotus ostreatus mushrooms was developed and used to assay the extent of browning. According to the scale, score 1 indicates no browning and score 7 indicates severe browning.

\section{Sensory evaluation}

Trained panelists $(n=12)$ evaluated odor, color, texture and overall acceptability. Fresh unwashed mushrooms were used as the control (where color $=1$, aroma $=1$ and overall acceptability $=7$ ). According to the scale to assess overall acceptability 9 indicated the sample was excellent, $7=$ very good, $5=\operatorname{good}$ and at the limit of marketability, 3 = fair and the limit of usability, and $1=$ poor and inedible. The color index described above was used to assess the post harvest browning of Pleurotus ostreatus. Aroma was assessed based on a scale of 1-9 where $9=$ full typical aroma, 7 = moderately full aroma, $5=$ moderate aroma, $3=$ slight aroma, and $1=$ no smell.

\section{Statistical analysis}

The parametric data were analysed using one way ANOVA and Tukey's multiple comparison method. The data obtained for color, aroma and the overall acceptability were analyzed using Kruskal Wallis method. All analyses were carried out using Minitab 16 software program.

\section{RESULTS}

Determination of ID $_{50}$ value of cinnamic acid on mushroom tyrosinase: The ID $_{50}$ for cinnamic acid was $3.42 \mathrm{mM}$ calculated from the graph of percent inhibition of tyrosinase enzyme vs $\log$ concentration of cinnamic acid (mM) as shown in the Figure 1. Each data point is the average of three measurements. 


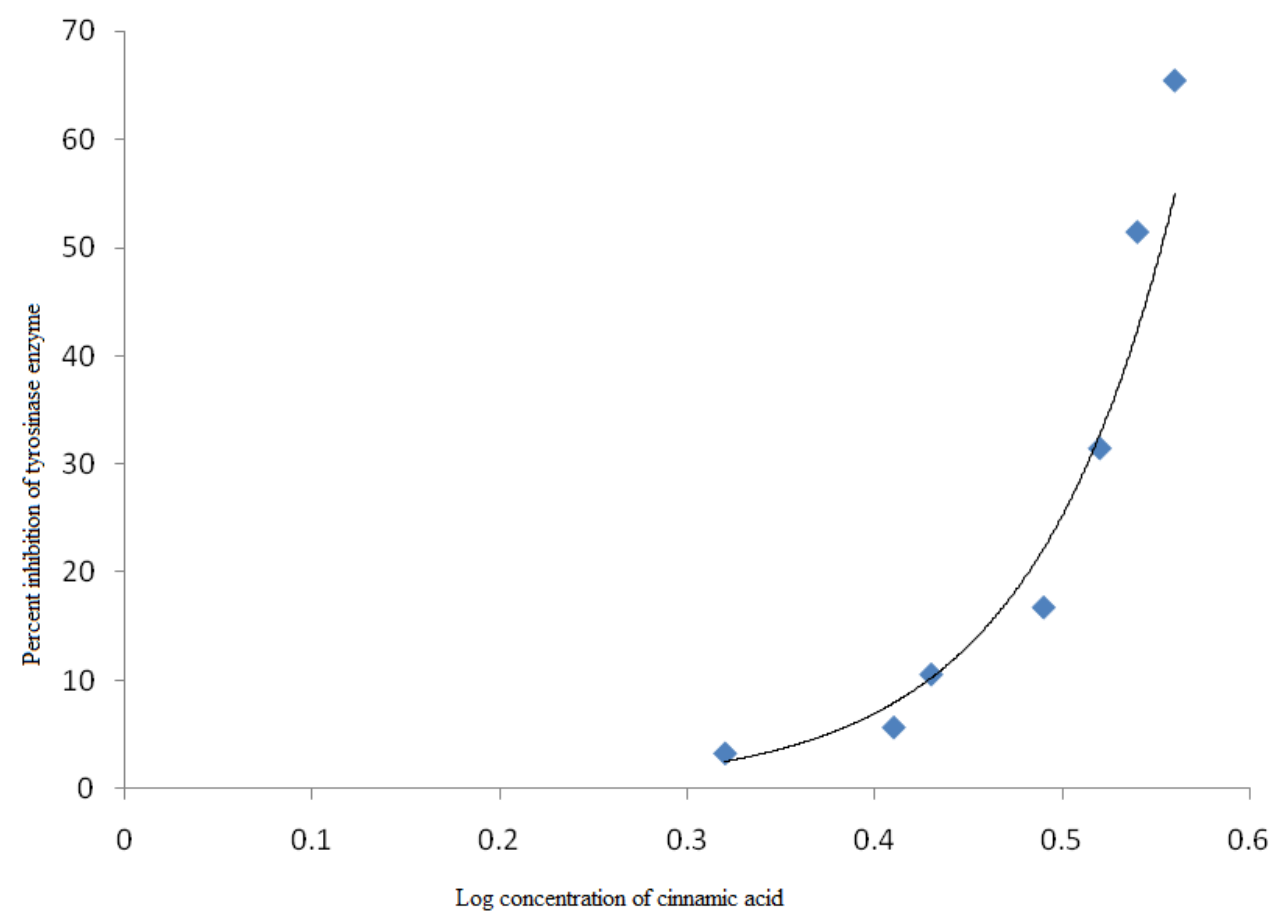

Figure 1: Log concentration of cinnamic acid $v s$ percent inhibition of tyrosinase enzyme. Each data point is an average of three measurements

Weight loss: In all treatments and the control samples weight loss increased as the storage period progressed. The minimum and the maximum percent weight loss obtained were $0.77 \pm 0.08 \%$ of mushroom samples treated with $2.00 \mathrm{mM}$ cinnamic acid and $2.35 \pm 0.28 \%$ of samples treated with $0.50 \mathrm{mM}$ cinnamic acid respectively. Each data point is the average of three measurements. (Figure 2)

Reflectance: It was expected for reflectance to decrease when browning increased. However the results do not reflect a correlation pattern. Each point of the graph given is the average of at least three measurements. 


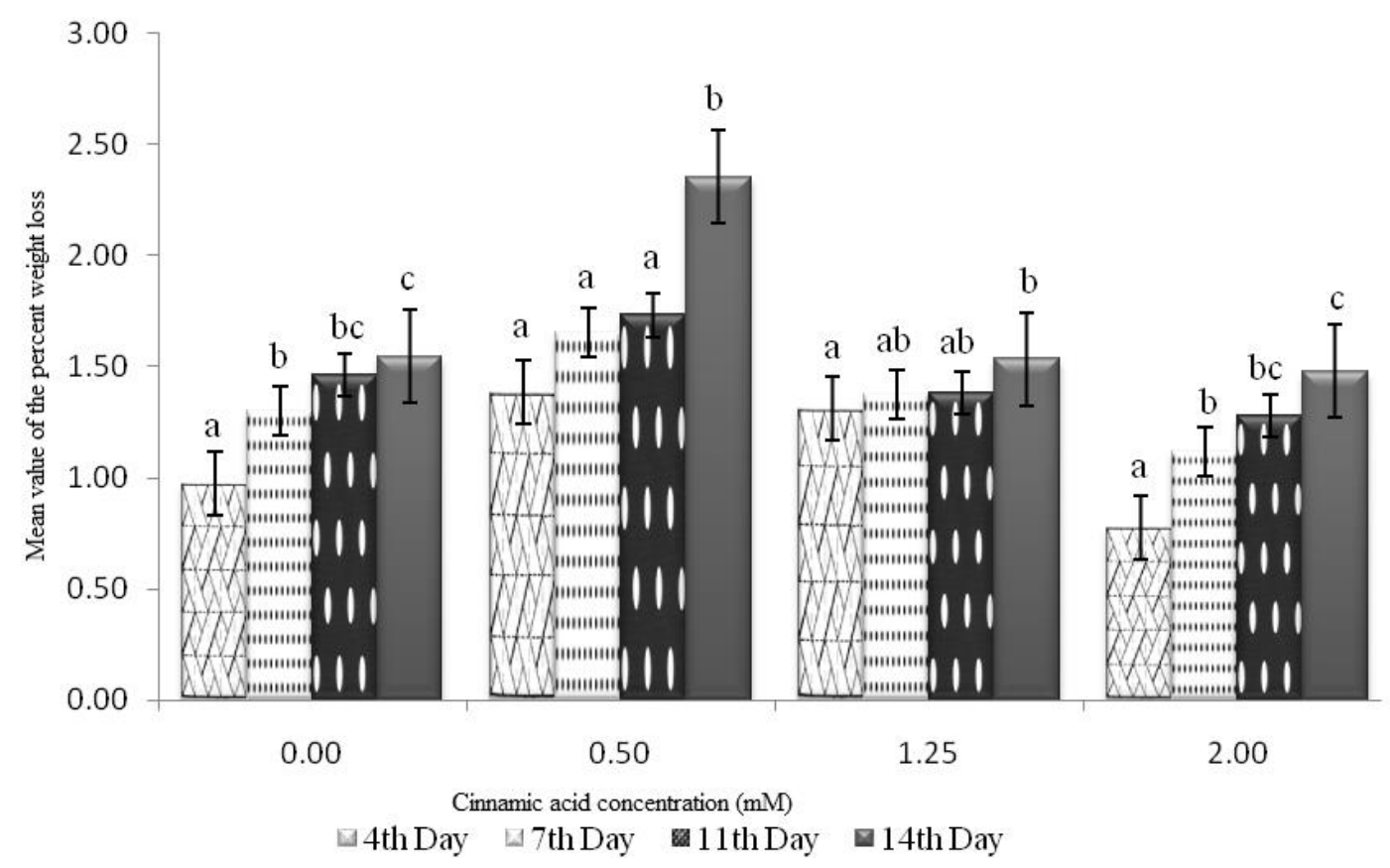

Figure 2: Cinnamic acid concentration $v s$ mean value of the percent weight loss on 4,7, 11 and 14 days of storage at $4^{\circ} \mathrm{C}$. Each data point is an average of three measurements.

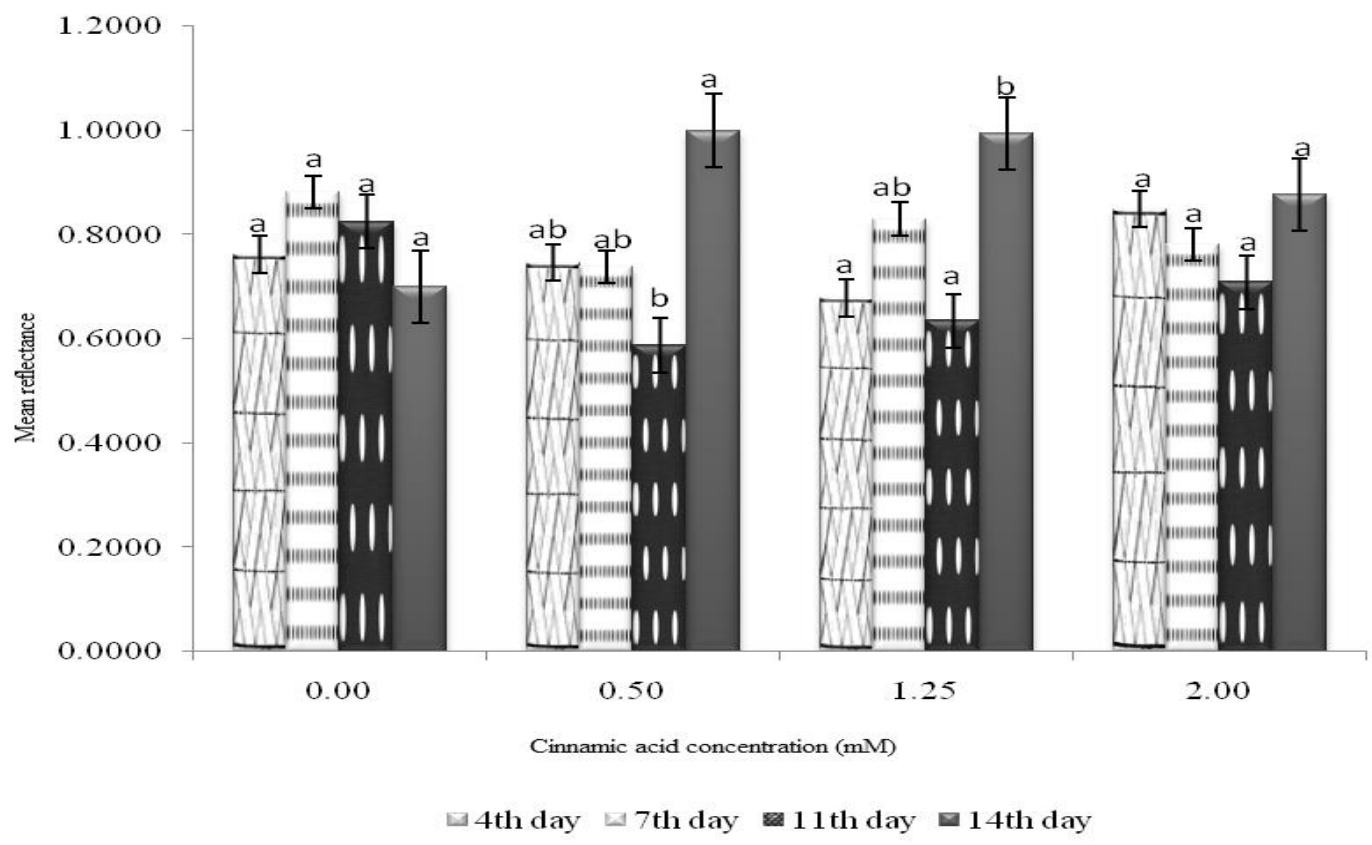

Figure 3: Cinnamic acid concentration $v s$ mean reflectance on 4, 7, 11 and 14 days of storage at $4^{\circ} \mathrm{C}$. Each data point is an average of three measurements. 
Color; The color of all the samples and controls did not show any significant difference up to 04 days storage at $4^{\circ} \mathrm{C}$. The samples treated with $1.25 \mathrm{mM}$ cinnamic acid did not show a significant change in color up to 11 days when compared with day 4 . The color of $0.50 \mathrm{mM}, 2.00 \mathrm{mM}$ cinnamic acid treated samples and control showed a significant change in the color after 11 days of storage. There was a rapid deterioration in the color in the control and treated samples on the $14^{\text {th }}$ day.

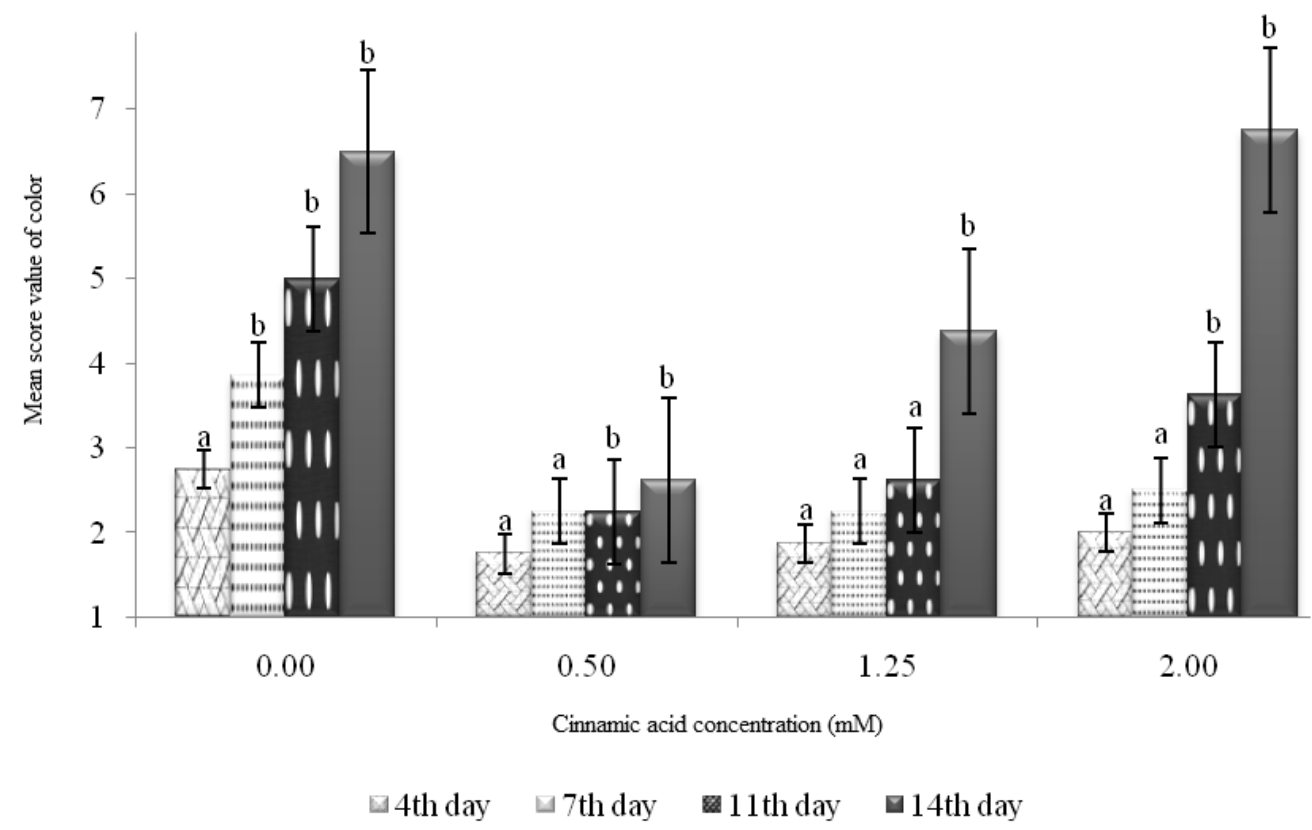

Figure 4: Cinnamic acid concentration vs mean score value of color on 4, 7, 11 and 14 days of storage at $4^{\circ} \mathrm{C}$. Each data point is an average of three measurements. Same letter on top of the column indicated no significant difference in the means when compared by Kruskal Wallis $(\mathrm{P} \geq 0.05)$ method.

Aroma; Aroma in all the controls and samples when compared with Kruskal Wallis method did not show any significant difference at the beginning of the storage period and maintained it up to 04 days. On the $7^{\text {th }}$ day of sampling the samples treated with $0.50 \mathrm{mM}$ and $2.00 \mathrm{mM}$ cinnamic acid showed a significant difference in aroma compared to day 4 , all the other samples and control did not indicate a significant change during this period. After 11 days the samples treated with $0.50 \mathrm{mM}, 1.25 \mathrm{mM}$ 
and $2.00 \mathrm{mM}$ cinnamic acid did not show a significant change in aroma compared with day 4 where as the control showed a significant rise in the aroma. Only the samples treated with $2.00 \mathrm{mM}$ cinnamic acid did not show any change in aroma up to 14 days compared with day 4. All the other treatment and controls showed a significant difference in aroma compared to day 4.

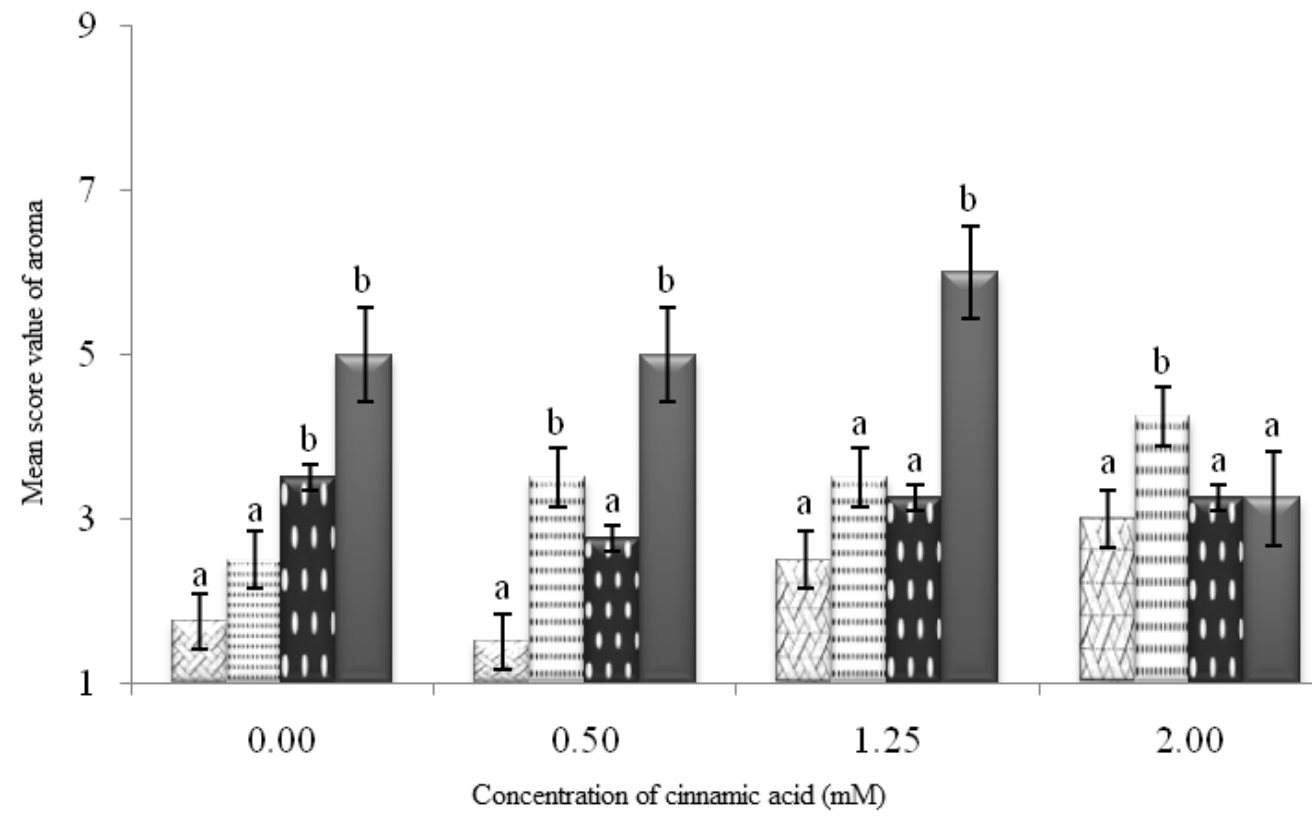

$\triangle 4$ th day $\triangle 7$ th day $\quad$ 器 11 th day $\square 14$ th day

Figure 5: Cinnamic acid concentration vs mean score value of aroma on 4, 7, 11 and 14 days of storage at $4^{\circ} \mathrm{C}$. Each data point is an average of three measurements. Same letter on top of the column indicated no significant difference in the means when compared by Kruskal Wallis $(\mathrm{P} \geq 0.05)$ method.

Overall acceptability; Results obtained for overall acceptability when compared using Kruskal Wallis method indicated samples treated with $1.25 \mathrm{mM}$ cinnamic acid did not show a significant difference in the overall acceptability after 11 days compared to day 4. In all the other treatments the overall acceptability dropped after 7 days of storage. 


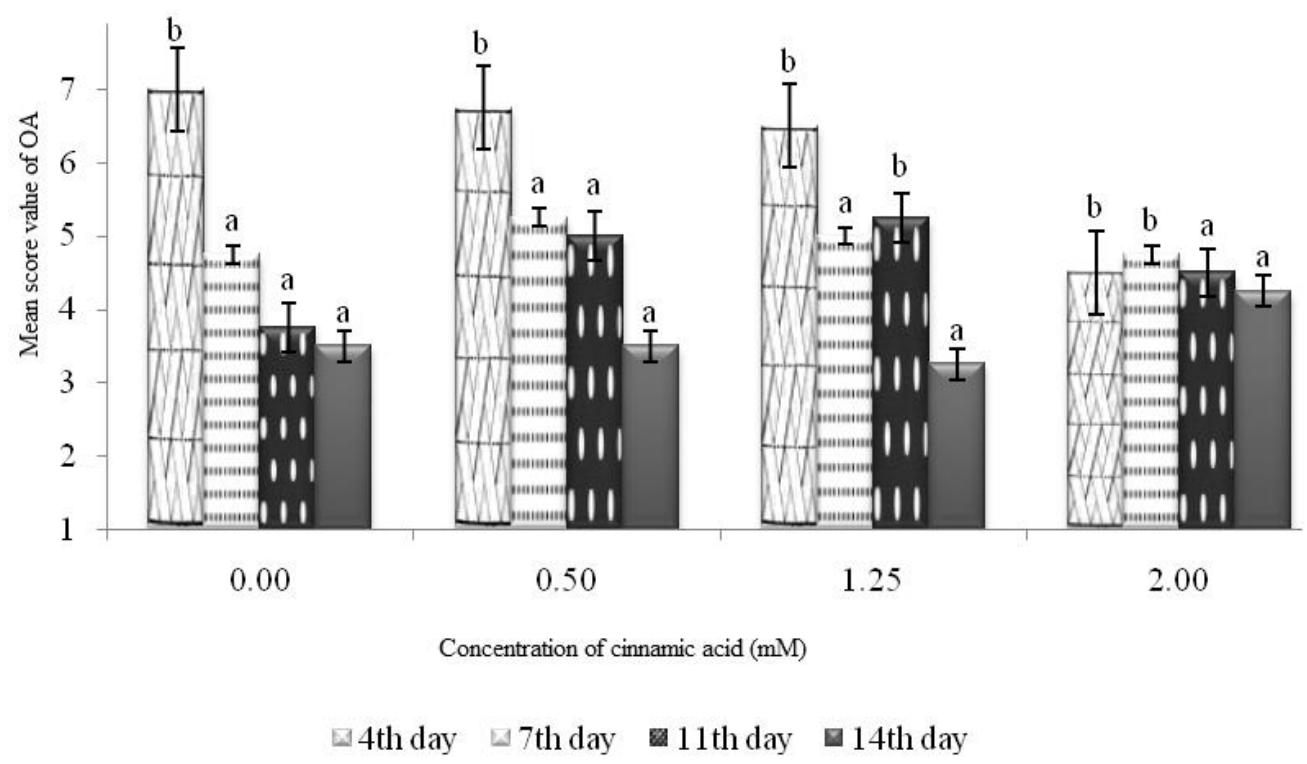

Figure 6: Cinnamic acid concentration vs mean score value obtained for overall acceptability (OA) on 4, 7, 11 and 14 days of storage at $4^{\circ} \mathrm{C}$. Each data point is an average of three measurements. Same letter on top of the column indicated no significant difference in the means when compared by Kruskal Wallis $(\mathrm{P} \geq 0.05)$ method.

\section{DISCUSSION}

Tyrosinase inhibitors have been the focus of attention of many studies in developing a post harvest strategy to extend the storage life of mushrooms. Polyphenol oxidase reaction is responsible for browning and deterioration of mushrooms quality during storage. In the current study a concentration close to the $\mathrm{ID}_{50}$ of polyphenol oxidase was used as a post harvest treatment. The concentration of cinnamic acid that was able to inhibit the tyrosinase activity by $50 \%$ was $3.42 \mathrm{mM}$. This was the first study to report the inhibitory effects of cinnamic on the activity of tyrosinase enzyme extracted from Pleurotus ostreatus. The $\mathrm{ID}_{50}$ of cinnamic acid on tyrosinase extracted from Agaricus bisporus was reported to be $2.10 \mathrm{mM}$. In this study after several preliminary investigations the samples were treated with $0.50 \mathrm{mM}, 1.25 \mathrm{mM}$ and 2.00 $\mathrm{mM}$ concentrations of cinnamic acid and stored in modified atmosphere packaging at $4^{\circ} \mathrm{C}$. Organoleptic properties, and weight loss was monitored on day 4, 7, 11 and 14 
days after storage. Reflectance was measured on a uniform size of the flesh to develop a non invasive technique to monitor the post harvest browning. However, there was no correlation between the post harvest browning and change of reflectance. The controls and treated samples did not show a significant change in the organleptic properties after 04 days of storage at $4^{\circ} \mathrm{C}$. Cinnamic acid is rated as a GRAS (Generally regarded as safe) compound and can be used on fresh fruits and vegetables. A concentration higher than $2.00 \mathrm{mM}$ resulted in rapid deterioration of the mushroom. As mushrooms perish very rapidly and have a very high respiration rate modified atmosphere packaging and low temperatures are also required to extend the storage life of mushrooms. Of the three concentrations used, $1.25 \mathrm{mM}$ was the most effective in extending the storage life of mushroom without affecting the organoleptic properties. Using modified atmosphere packaging and $1.25 \mathrm{mM}$ cinnamic acid the shelf life of mushrooms can be extended up to 11 days at $4^{\circ} \mathrm{C}$. As mentioned above untreated samples and some treated samples showed a significant deterioration in the organleptic properties after 04 days of storage at $4^{\circ} \mathrm{C}$.

\section{CONCLUSION}

Immersing in a $1.25 \mathrm{mM}$ cinnamic acid solution for 5 minutes and packaging in polyethelene bags in 3;1 surface area to weight ratio and storing at $4^{\circ} \mathrm{C}$ can be recommended as an integrated treatment to extend the storage life of Pleurotus ostreatus up to 11 days.

\section{REFERENCE}

Alam N., Amin R., Khan A., Ara I., Shim M.J., Lee M.W. and Lee T.S., 2008. Nutritional analysis of cultivated mushrooms in Bangladesh. Pleurotus ostreatus, Pleurotus sajor-caju, Pleurotus Florida and Calocybe indica. Mycobiology 36(4): 228-232.

Ares G., Lareo C. and Lema P., 2007. Modified Atmosphere Packaging for Post-harvest Storage of Mushrooms. A Review. Fresh Produce 1(1): 32-40. 
Brennan M., Port G.L. and Gormley R., 2000. Post- harvest Treatment with Citric Acid or Hydrogen Peroxide to Extend the Shelf Life of Fresh Sliced Mushrooms. Lebensmittel-Wissenshaft und Technologie 33: 285-289.

Haghbeen K., Jazii F. R., Karkhane A. A. and Borojerdi S. S., 2004. Purification of tyrosinase from edible mushroom. Iranian Journal of Biotechnology 2(3): 189194.

Horowitz N., Fling M., Macleod H. and Sueoka N., 1960. Genetic determination and enzymatic induction of tyrosinase in Neurospora+++. Journal of Molecular Biology 2(2): 96-104.

Jolivet S., Arpin N., Wichers H.J. and Pellon G., 1998. Agaricus bisporus browning: a review. Mycology Research 102(12): 1459-1483.

Kalac P., 2013. A review of chemical composition and nutritional value of wildgrowing and cultivated mushroom. Journal of the Science of food and Agriculture 93: 209-218.

Kumara K.L.W. and Edirimanna I.C.S., 2009. Improvement of two Oyster mushroom Cultivars using Dual Culture Technique. Journal of World Applied Science 17 (5): 654-660.

Masamoto Y., Lida S. and Kubo M., 1980. Inhibitory Effect of Chinese Crude Drugs on Tyrosinase. Journal of Medicinal Plant Research 40: 361-365.

Rajapakse J.C., Rubasingha P. and Dissanayake N.N., 2007. The Potential of Using Cost-Effective Compost Mixtures for Oyster Mushroom (Pleurotus spp) Cultivation in Sri Lanka. Tropical Agricultural Research \& Extension 10: 2932.

Shi Y., Chen Q.X., Wang Q., Song K.K. and Qiu L., 2005. Inhibitory effects of cinnamic acid and its derivatives on the diphenolase activity of mushroom (Agaricus bisporus) tyrosinase. Food Chemistry 92: 707-712. 